\title{
Characterisation of epitopes of pan-IgG/anti-G3m(u) and anti-Fc monoclonal antibodies
}

\author{
Paul N. Nelson ${ }^{\mathrm{a}, *}$, Olwyn M.R. Westwood ${ }^{\mathrm{b}, \mathrm{c}}$, Andy Soltys ${ }^{\mathrm{b}}$, Roy Jefferis ${ }^{\mathrm{d}}$, \\ Margaret Goodall ${ }^{\mathrm{d}}$, Karl R.N. Baumforth ${ }^{\mathrm{e}}$, Geoff Frampton ${ }^{\mathrm{a}}$, Gordon Tribbick ${ }^{\mathrm{f}}$, \\ Denise Roden ${ }^{\mathrm{a}}$, Frank C. Hay ${ }^{\mathrm{b}}$ \\ ${ }^{a}$ Molecular Immunology Research Group, Division of Biomedical Sciences, University of Wolverhampton, Wulfruna Street, Wolverhampton WV1 1SB, \\ $U K$ \\ ${ }^{\mathrm{b}}$ Department of Immunology, St. George's Hospital Medical School, London, UK \\ ${ }^{\mathrm{c}}$ Swansea Clinical School, University of Wales Swansea, Swansea, UK \\ d Department of Immunology, The Medical School, University of Birmingham, Birmingham, UK \\ ${ }^{\mathrm{e}}$ Department of Pathology, The Medical School, University of Birmingham, Birmingham, UK \\ ${ }^{\mathrm{f}}$ Chiron, Melbourne, Australia
}

Received 10 December 2002; received in revised form 8 March 2003; accepted 17 March 2003

\begin{abstract}
The characterisation of monoclonal antibodies (MAbs) and their epitopes is important prior to their application as molecular probes. In this study, Western blotting using $\mathrm{IgG1} F \mathrm{~F}$ and $\mathrm{pFc}^{\prime}$ fragments was employed to screen seven MAbs before pepscan analysis to determine their reactivity to potentially linear epitopes. MAbs PNF69C, PNF110A, X1A11 and MAbs WC2, G7C, JD312, 1A1 detected epitopes within the $\mathrm{C}_{\mathrm{H}} 3$ and $\mathrm{C}_{\mathrm{H}} 2$ domains, respectively. However, only four MAbs showed pepscan profiles that highlighted likely target residues. In particular, MAbs PNF69C and PNF110A that have previously been characterised with pan-IgG and anti-G3m(u) specificity, detected the peptide motif 338-KAKGQPR-344 which was located within the N-terminal region of the $\mathrm{C}_{\mathrm{H}} 3$ domain. Furthermore the majority of residues were present in all four IgG subclasses. Consequently the peptide identified was consistent with the pan-IgG nature of these antibodies. By using PCImdad, a molecular display programme, this sequence was visualised as surface accessible, located in the $\mathrm{C}_{\mathrm{H}} 2 / \mathrm{C}_{\mathrm{H}} 3$ inter-domain region and proximal to the residue arginine 435 . It is speculated that this residue may be important for phenotypic expression of $\mathrm{G} 3 \mathrm{~m}(\mathrm{u})$ and specificity of these reagents. Pepscan analysis of MAbs G7C and JD312 (both pan-IgG) highlighted the core peptide sequence 290-KPREE-294, which was present in the $\mathrm{C}_{\mathrm{H}} 2$ domain and was common to all four IgG subclasses. PCImdad also showed this region to be highly accessible and was consistent with previous bioinformatic and autoimmune analysis of IgG. Overall these MAbs may serve as useful anti-IgG or anti$\mathrm{G} 3 \mathrm{~m}(\mathrm{u})$ reagents and probes of immunoglobulin structure.
\end{abstract}

(C) 2003 Elsevier Science B.V. All rights reserved.

Keywords: Monoclonal antibodies; Assay restriction; Epitope mapping; IgG allotypes

\section{Introduction}

Assay restriction is a common feature and problem of monoclonal antibodies (MAbs). In essence, MAbs may perform well in some assay systems but may be poor or ineffective in others $[1,2]$. In addition, the specificity of a given reagent can also be determined by the assay

\footnotetext{
* Corresponding author. Tel.: +44-1902-32-1152; fax: +44-190232-2714.

E-mail address: p.n.nelson@wlv.ac.uk (P.N. Nelson).
}

system employed [3]. This phenomenon relates to the nature and display of the antigenic determinant, or epitope, and whether it is modified (or denatured) as a result of procedures used within an assay technique [3]. Consequently the characteristics of an antibody's target epitope in terms of location, composition of amino acids and accessibility are highly significant together with issues of antibody specificity and reactivity in the development of secure assay systems [4]. To this end, pepscan methodologies which employ a series of overlapping synthetic peptides of a given protein have 
provided an effective means of identifying key residues for antibody recognition and binding [5]. Overall, pepscan analysis employing peptides immobilised on polyethylene pins has been satisfactorily used to identify $\mathrm{MAb}$ reactivity to continuous epitopes [6]. However, a disadvantage of this particular methodology has been the uncertainty of peptide regeneration and thus pepscan using biotinylated peptides (attached to streptavidin coated plates) has also been employed [7]. In general, pepscan methodologies provide greater resolution of target residues compared with gross epitope mapping techniques such as enzyme degradation and cyanogen bromide cleavage, which allow the localisation of antibody reactivity to particular fragments [1].

Monoclonal reagents are widely used within the biomedical sciences and readily enable the standardisation of both reagent and assay technique because they are specific and can be generated in unlimited quantities in vitro [8]. Earlier studies [9,10] have demonstrated two MAbs (PNF69C and PNF110A) with assay restriction profiles. Of interest is that both MAbs exhibit pan-IgG and anti-G3m(u) specificity in indirect ELISA/haemagglutination (HA) and capture ELISA/haemagglutination-inhibition (HAI), respectively. Both MAbs were derived from the same fusion but originated from different hybridoma cell lines. Both reagents may prove useful pan-IgG or anti-allotypic antibodies e.g. for clinical/forensic serology [11], although the target epitope(s) recognised by these antibodies remains unclear.

A previous report [12] has successfully employed biotinylated 15 mer overlapping peptides of $\operatorname{IgG} \mathrm{Fc}$ to identify the target epitope of an in-house and commercially available pan-IgG monoclonal reagent, $\mathrm{MAb}$ A57H. This antibody recognised a peptide sequence 383-SNGQPENN-390 (Eu numbering, single amino acid code) that was found on all four $\operatorname{IgG}$ subclasses and straddled the fy1 strand and the b3 loop of the $\mathrm{C}_{\mathrm{H}} 3$ domain [13]. As an extension to this work, we have used these peptides to map potential epitopes of MAbs PNF69C and PNF110A and five other anti-IgG Fc MAbs (X1A11, WC2, G7C, JD312, 1A1) previously characterised with regard to subclass specificity. Furthermore by employing a software programme 'PCImdad' we have been able to demonstrate the surface topography and accessibility of potential IgG target epitope's identified through pepscan analysis.

\section{Materials and methods}

\subsection{Monoclonal antibodies}

The generation and specificity of MAbs used in this study (PNF69C, PNF110A, X1A11, WC2, G7C, JD312 and 1A1) with regard to IgG subclass, allotypic $(\mathrm{Gm})$ markers, deleted paraproteins and $\mathrm{IgG}$ fragments have previously been reported $[9,14-16]$. These reagents have been characterised using a combination of techniques including haemagglutination (HA), haemagglutinationinhibition (HAI) and enzyme linked immunosorbent assay (ELISA). Five MAbs (TM15, ZB8, GOM1, ZG4 and RJ4) with reactivity to regions other than IgG1 Fc were used as controls and represented the predominant mouse isotype under investigation. Ascites $(1 \mathrm{mg} / \mathrm{ml})$ was used as a source of monoclonal reagent for all investigations.

\subsection{Western blot analysis}

Western blotting of MAbs was performed using standard procedures [1] on previously characterised paraproteins: PER (IgG1 Fc), $\mathrm{pFc}$ ' PER (pepsin digestion product of $\mathrm{Fc} P E R)[2,12-14]$ to ascertain reactivity to linear antigenic determinants. In brief, equal amounts $(5 \mu \mathrm{g})$ of immunoglobulin preparations either containing 2-mercaptoethanol (denatured) or without reducing agent, were separated on SDS- $12 \%$ polyacrylamide Laemmli gels. Proteins were then transferred onto nitrocellulose membrane (Hybond-C: Amersham Pharmacia Biotech Ltd., Little Chalfont, UK) and membranes blocked using 5\% milk powder (Marvel) in PBS/ Tween $(0.1 \%)$. MAbs were used at a concentration of 30 $\mu \mathrm{g} / \mathrm{ml}$ diluted in PBS/Tween (0.1\%). An anti-mouse horseradish peroxidase-conjugated secondary antibody (DAKO, UK) was used for the detection of transferred bands in conjunction with the enhanced chemiluminescence system (ECL, Amersham-Pharmacia Biotech UK Ltd.). The standard immunodetection protocol as detailed in the ECL handbook was used and the exposure time was $15 \mathrm{~s}$.

\subsection{Synthetic peptides}

Ninety-four 15 mer peptides were provided by Mimotopes Pty Ltd., based on the human IgG1 Fc region, sequence NIE [17] and biotinylated at the N-terminus. Peptides were initially reconstituted in $200 \mu 1$ DMSO and subsequently diluted in phosphate buffer diluent (see below) to give a final concentration of $1 \mathrm{nmol} / \mathrm{ml}$. Peptides spanned most of the $\mathrm{C}_{\mathrm{H}} 2$ and $\mathrm{C}_{\mathrm{H}} 3$ domains: commencing 238-PSVFLFPPKPKDTLM-252 and terminating 424-FSCSVMHEALHNHYT-438. All residues were related to the Eu numbering index [17] and the offset for overlapping peptides was two e.g. SRDELTKNQVSLTCL (354-368), DELTKNQVSLTCLVK (356-370). Sequences NIE and EU are virtually identical [17] although NIE possesses an additional residue: aspartic $\operatorname{acid}_{389}$. In addition, EU and NIE exhibit amino acid replacements of glutamic acid 294 with glutamine 294 , respectively. 


\subsection{Pepscan assay}

Flat bottomed plastic microtitre plates (Nunc: Life Technologies, Paisley, UK) were coated with $100 \mu \mathrm{l}$ of a $5 \mu \mathrm{g} / \mathrm{ml}$ solution of streptavidin (Sigma, Poole, UK) and left uncovered at $37^{\circ} \mathrm{C}$ for at least $16 \mathrm{~h}$ until they had evaporated to dryness. The plates were washed using tapwater and each well blocked with $200 \mu \mathrm{l}$ of a $2 \%$ solution of BSA in $0.1 \mathrm{M}$ PBS pH 7.2. Plates were incubated for $1 \mathrm{~h}$ at room temperature, with agitation, and washed $(\mathrm{x} 4)$ in PBS/Tween $20(0.1 \% \mathrm{v} / \mathrm{v})$. Peptides were prepared in diluent: PBS containing Tween 20 $(0.1 \% \mathrm{v} / \mathrm{v})$ and sodium azide $(0.1 \% \mathrm{w} / \mathrm{v})$, and $100 \mu \mathrm{l}$ added to each well (ca. $30 \mathrm{pmol}$ of biotinylated peptide per well). Plates were incubated for $1 \mathrm{~h}$ at room temperature, with agitation, and then washed $(\mathrm{x} 4)$ in $\mathrm{PBS} /$ Tween. MAb ascites were diluted 1/1000 in diluent and added to wells $(100 \mu 1)$. Plates were incubated for 1 $\mathrm{h}$ at room temperature with agitation and then washed (x4). Finally peroxidase-conjugated goat anti-mouse immunoglobulin (DAKO, Cambridge, U.K.) was optimally diluted (1/1000) in $0.01 \mathrm{M}$ PBS pH 7.2 containing $1 \% \mathrm{v} / \mathrm{v}$ sheep serum, $0.1 \% \mathrm{v} / \mathrm{v}$ Tween $20,0.1 \% \mathrm{w} / \mathrm{v}$ sodium caseinate and applied to wells $(100 \mu 1 /$ well): plates were incubated for $1 \mathrm{~h}$ at room temperature with agitation. Following washing, $100 \mu 1$ of ABTS (Sigma, Poole, UK) substrate (dissolved in $0.1 \mathrm{M}$ di-sodium hydrogen orthophosphate, $0.08 \mathrm{M}$ citric acid) containing $0.01 \% \mathrm{w} / \mathrm{v}_{2} \mathrm{O}_{2}$ was added to each well. The colour reaction was allowed to proceed for $30 \mathrm{~min}$ and the $\mathrm{OD}$ read at $405 \mathrm{~nm}$ using a Titertek Multiscan MC microplate reader. OD values were provided as $0-2000$ nominal OD Units (equivalent to the generally accepted format $0.0-2.0$ OD Units) [1-3]. The OD values

Table 1

Reactivity of MAbs in Western blotting using IgG1 Fc and $\mathrm{pFc}^{\prime}$ fragments

\begin{tabular}{|c|c|c|c|c|}
\hline \multirow[t]{2}{*}{ Mab } & \multicolumn{2}{|l|}{$\mathrm{Fc}(\mathrm{PER})$} & \multicolumn{2}{|c|}{$\mathrm{pFc}^{\prime}(\mathrm{PER})$} \\
\hline & Non-red. & Red. & Non-red. & Red. \\
\hline PNF69C & + & + & + & $+\mathrm{w}$ \\
\hline PNF110A & + & + & + & + \\
\hline X1A11 & + & + & + & + \\
\hline WC2 & + & NT & - & NT \\
\hline G7C & + & + & - & - \\
\hline JD312 & + & + & - & - \\
\hline $1 \mathrm{~A} 1$ & + & NT & + & NT \\
\hline \multicolumn{5}{|l|}{ Controls } \\
\hline $\mathrm{A} 57 \mathrm{H}$ & + & + & + & + \\
\hline A55 & + & + & - & - \\
\hline
\end{tabular}

MAbs were evaluated for reactivity in Western blotting against nonreduced (non-red.) and reduced (red.) paraproteins Fc(PER) (MW 50 KDa) $[9,15]$ and the pepsin derived fragment $\mathrm{pFc}^{\prime}$ (PER) (MWt 25 KDa) $[9,15] .+$ (positive), - (negative), NT (not tested), w (weak band). Control MAbs A55 and $\mathrm{A} 57 \mathrm{H}$ detected $\mathrm{C}_{\mathrm{H}} 2$ and $\mathrm{C}_{\mathrm{H}} 3$ domains, respectively. obtained from control MAbs were used to determine a mean value for each peptide that was subtracted from all other Pepscan profiles (for controls: range, 94-1071 OD Units; mean, 230 OD Units, maximum OD [peptide 62, 360-KNQVSLTCLVKGFYP-374, followed by peptide 61, 358-LTKNQVSLTCLVKGF-372]).

\subsection{PCImdad display}

A PC interactive molecular display and design programme (PCImdad) [18] was used to display potential amino acids on the $\mathrm{Fc}$ region of $\mathrm{IgG}$ derived from Pepscan data. Key residues were highlighted and displayed, employing space-filling and carbon backbone modes, on an IgG Fc molecule [19].

\section{Results}

\subsection{Western blotting}

To ascertain the reactivity to potential linear epitopes within IgG Fc, seven MAbs (PNF69C, PNF110A, X1A11, WC2, G7C, JD312, 1A1) were evaluated by Western blotting. In this system, both reduced and nonreduced $\mathrm{Fc}$ and $\mathrm{pFc}^{\prime}$ fragments were used and their electrophoretic transfer to nitrocellulose validated by previously characterised antibodies. The data (Table 1) highlighted that MAbs PNF69C and PNF110A detected both reduced and non-reduced $\mathrm{pFc}^{\prime}$ (PER). MAbs $\mathrm{X} 1 \mathrm{~A} 11$ and $1 \mathrm{~A} 1$ were reactive with $\mathrm{Fc}$ and $\mathrm{pFc}^{\prime}$ fragments whilst MAbs WC2, G7C and JD312 were reactive with $\mathrm{Fc}(\mathrm{PER})$, but not $\mathrm{pFc}^{\prime}$ (PER).

\subsection{Pepscan profiling}

Out of seven antibodies tested, only four MAbs (PNF69C, PNF110A, G7C and JD312) generated Pepscan profiles. MAbs X1A11, WC2 and 1A11 showed similar reactivity to peptides as control antibodies. The Pepscan profile for MAb PNF69C (Fig. 1a) highlighted antibody activity for peptides $47-51$ with OD's ranging from 1500 to $2000 \mathrm{OD}$ units. Identical peptides were detected by MAb PNF110A (not shown) that on alignment suggested a core peptide sequence: 338KAKGQPR-344. Both antibodies exhibited reactivity for peptides 61 (358-LTKNQVSLTCLVKGF-372) and 62 (360-KNQVSLTCLVKGFYP-374) that was also noted for all control MAbs tested. MAb G7C identified peptides $23-26$ (Fig. 2a) with antibody activity ranging from 1500 to 2000 OD units. Marginally higher activity (2000-2500 OD units) was also shown by MAb JD312 and included peptides 22-27. Alignment of peptides for MAbs G7C and JD312 highlighted the core sequence: 290-KPREE-294. 
(a)

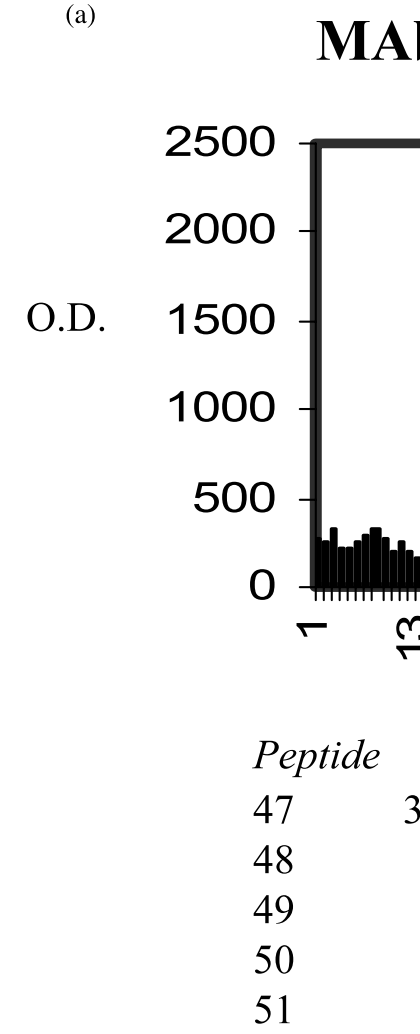

(b)

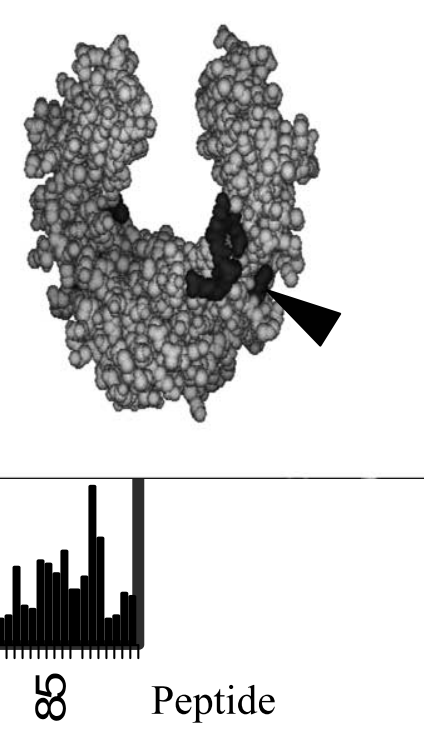

$\begin{array}{lc}\text { Peptide } & \text { Amino Acid Sequence } \\ 47 & \text { 330-APIEKTISKAKGQPR-344 } \\ 48 & \text { 332-IEKTISKAKGQPREP-346 } \\ 49 & \text { 334-KTISKAKGQPREPQV-348 } \\ 50 & \text { 336-ISKAKGQPREPQVYT-350 } \\ 51 & 338 \text {-KAKGQPREPQVYTLP-352 }\end{array}$

Fig. 1. (a) Pepscan anlaysis of MAb PNF69C. The profile for MAb PNF110A was similar and specific details are presented in text. (b) PCImdad of peptide sequence 338-KAKGQPR-344 plus the position (arrowed) of arginine ${ }_{435}$.

\subsection{PCImdad display}

The location and surface topography of likely target epitopes was visualised on an IgG molecule using the space-filling mode. The core sequence 338-KAKGQPR344 (Fig. 1b) was present on an exposed peptide segment (or loop) that bridged the fy 3 face and the fx 1 face of the $\mathrm{C}_{\mathrm{H}} 2$ and $\mathrm{C}_{\mathrm{H}} 3$ domains, respectively. Conversely the peptide sequence 290-KPREE-294 was located on the fx3 face of the $\mathrm{C}_{\mathrm{H}} 2$ domain which was exposed and solvent accessible (Fig. 2b) and thus capable of interaction with antibody.

\section{Discussion}

Epitope mapping using pepscan provides a useful adjunct to the characterisation of MAbs [4] and has been used in identifying epitopes on macromolecules including allergens and components of viruses [20,21]. However, an important caveat of pepscan is that the technique is biased towards antibodies recognising linear, as opposed to conformational epitopes. Petrakou et al., [22] showed that only half of the MAbs investigated using overlapping peptides of MUC1 mucin yielded pepscan profiles. To circumvent this problem, we initially tested our panel of MAbs in Western blotting since the detergent sodium dodecyl sulphate effectively linearises proteins for gel separation prior to their transfer to nitrocellulose membrane [1]. In our study all seven MAbs exhibited reactivity in Western blotting: MAbs PNF69C, PNF110A, X1A11, 1A1 to $\mathrm{pFc}^{\prime}(\mathrm{PER})$ and MAbs WC2, G7C, JD312 to Fc(PER). Since pepsin cleaves C-terminal to glutamic $\operatorname{acid}_{333}$ to yield a $\mathrm{pFc}^{\prime}$ fragment [13], it may be inferred that MAbs WC2, G7C and JD312 bound to epitopes within the $\mathrm{C}_{\mathrm{H}} 2$ domain of $\mathrm{Fc}(\mathrm{PER})$. Whilst it has been recognised that some renaturation of proteins may occur following SDS leaching i.e. during electrophoretic transfer [23], it was likely that these antibodies bound to potentially linear $\mathrm{Fc}$ epitopes. Overall preliminary evaluation of antibodies in Western blotting confirmed previous $\mathrm{C}_{\mathrm{H}} 2 /$ $\mathrm{C}_{\mathrm{H}} 3$ localisation studies of anti-Fc MAbs $[9,15,16]$ but was only partially successful since MAbs X1A11, WC2 and $1 \mathrm{~A} 1$ did not yield pepscan profiles. In explanation, it was plausible that these antibodies recognised quasilinear epitopes that were perhaps conformationally constrained by amino acids upstream/downstream of the target site. Furthermore, the weaker reactivity of MAb PNF69C for its epitope on reduced $\mathrm{pFc}^{\prime}$ may also suggest some conformational constraints. Clearly the use of small isolated peptides attached to microtiter 
(a)

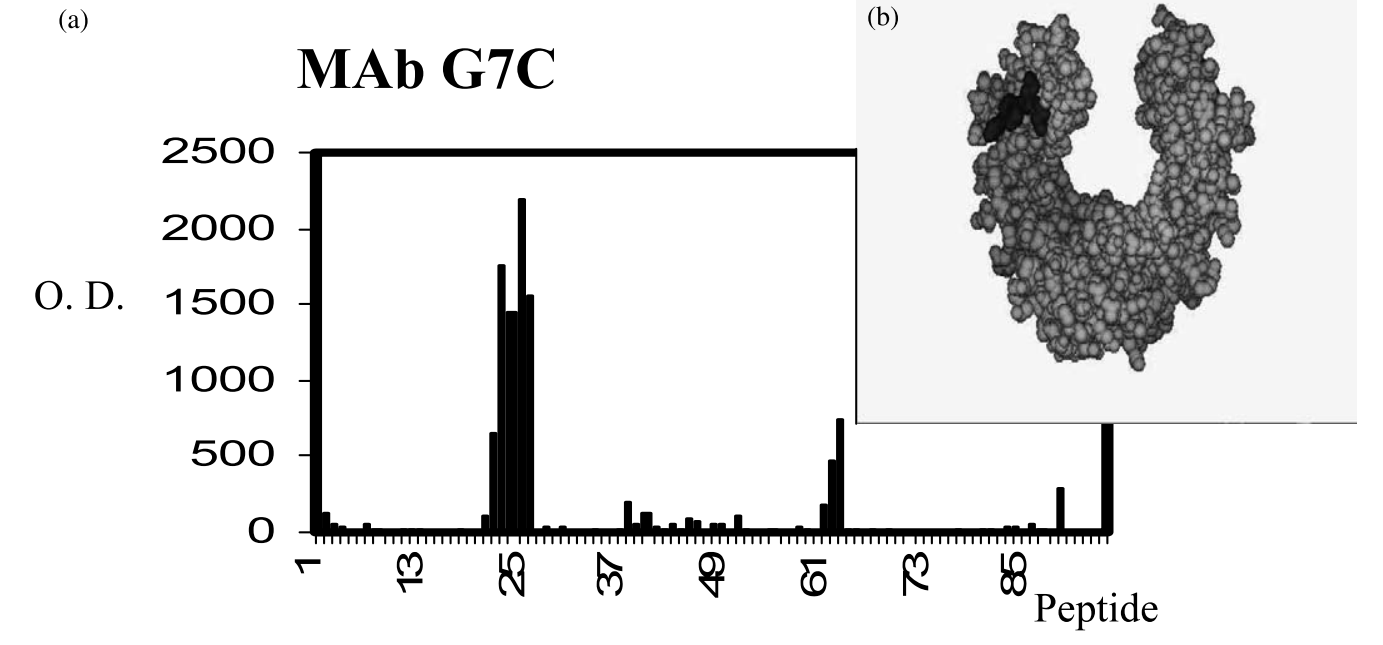

$\begin{array}{lc}\text { Peptide } & \text { Amino Acid Sequence } \\ 22 & \text { 280-DGVEVHNAKTKPREE-294 } \\ 23 & \text { 282-VEVHNAKTKPREEQY-296 } \\ 24 & \text { 284-VHNAKTKPREEQYNS-298 } \\ 25 & \text { 286-NAKTKPREEQYNSYT-300 } \\ 26 & \text { 288-KTKPREEQYNSTYRV-302 } \\ 27 & \text { 290-KPREEQYNSTYRVVS-304 }\end{array}$

Fig. 2. (a) Pepscan anlaysis of MAb G7C. The profile for MAb JD312 was similar and specific details are presented in text. (b) PCImdad of peptide sequence 290-KPREE-294.

plate wells may have compromised antibody-epitope interactions and it will be of interest to further evaluate the epitopes of MAbs X1A11, WC2 and 1A1 using sitedirected mutagenesis [24] and phage display [25].

For MAbs PNF69C and PNF110A pepscan analysis highlighted the core peptide sequence 338-KAKGQPR344 which was located at a position that included $\mathrm{C}_{\mathrm{H}} 2 /$ $\mathrm{C}_{\mathrm{H}} 3$ interdomain residues and the $\mathrm{N}$-terminal region of the $\mathrm{C}_{\mathrm{H}} 3$ domain. Furthermore this motif was present in all four IgG subclass proteins, although alanine 339 was substituted for threonine 339 in IgG2 and IgG3 allotypic variants (Table 2). A previous study [9] suggests that the pan-IgG reactivity of both MAbs was independent of this amino acid substitution. Thus pepscan of MAbs PNF69C and PNF110A highlights a common IgG subclass epitope that explains the pan-IgG nature of these reagents. In using PCImdad the peptide was characterised as highly accessible and, therefore, likely to be antigenic. Interestingly epitope mapping of polyclonal and monoclonal rheumatoid factors [26-28] highlights three $\mathrm{C}_{\mathrm{H}} 3$ domain epitopes (343-PREPQVY-349，346-PQVYTLP-352，350-TLPPSRE-356) that either overlap or are immediately adjacent to the peptide motif 338-KAKGQPR-344. Taken together, these studies reveal a highly antigenic region targeted by autoimmune antibodies [28] and MAbs developed in mice [9]. Evidently from previous studies using intact IgG $[9,15,16]$ the glycan moiety does not appear to hinder the accessibility of MAbs PNF69C and PNF110A for their target epitopes.

The location of the $\mathrm{G} 3 \mathrm{~m}(\mathrm{u})$ allotypic marker has previously been suggested to reside within the $\mathrm{C}_{\mathrm{H}} 2$ domain of IgG3 and its expression linked to the presence of threonine $339\left(\mathrm{C}_{\mathrm{H}} 2\right.$ domain $)$ and possibly arginine $_{435}$ in the $\mathrm{C}_{\mathrm{H}} 3$ domain $[29,30]$. However, current sequencing information [17] does not support a role for threonine 339 since Table 2 reveals that $\mathrm{G} 3 \mathrm{~m}(\mathrm{u})$ paraproteins WI and OM contain threonine ${ }_{339}$ and alanine $_{339}$, respectively, whilst paraprotein JIR G3m(st) possesses threonine ${ }_{339}$. This observation is also confirmed by Dard et al. [31] who investigated IgG3 allotypes in human populations other that $\mathrm{G} 3 \mathrm{~m}(\mathrm{u})$. In our studies it was also apparent that alanine 339 was present within the peptide sequence 338-KAKGQPR344. Overall these observations suggest that the presence alanine/threonine $_{339}$ may be less significant in the phenotypic expression of $\mathrm{G} 3 \mathrm{~m}(\mathrm{u})$. Consequently this allotypic marker may be conformationally dependent and necessitate one or more additional residues on IgG3. Intriguingly Table 2 shows that $\mathrm{IgG} 3$ variants expressing $\mathrm{G} 3 \mathrm{~m}(\mathrm{gu})$ and $\mathrm{G} 3 \mathrm{~m}(\mathrm{bu})$ possess $\operatorname{arginine}_{435}$ whilst $\operatorname{IgG} 1, \operatorname{IgG} 2, \operatorname{IgG} 4$ and $\mathrm{G} 3 \mathrm{~m}(\mathrm{st})$ paraproteins 
Table 2

Location of motifs identified through pepscan within $\operatorname{IgG}$ subclasses and Gm allotypic variants

\begin{tabular}{|c|c|c|c|c|c|c|c|c|c|}
\hline & \multirow[t]{2}{*}{ Eu index } & \multicolumn{2}{|l|}{ IgG1 } & \multirow{2}{*}{$\begin{array}{l}\text { IgG2 } \\
\mathrm{Cl}(\mathrm{n})\end{array}$} & \multicolumn{3}{|l|}{$\mathrm{IgG3}$} & \multicolumn{2}{|c|}{$\mathrm{IgG} 4$} \\
\hline & & $\mathrm{Eu}(\mathrm{f})$ & $\mathrm{Cl}(\mathrm{za})$ & & WI(bu) & $\mathrm{OM}(\mathrm{gu})$ & a JIR(st) & $\mathrm{Cln}$ & G4m(a) \\
\hline & 290 & Lys & Lys & Lys & Lys & Lys & Lys & Lys & Motif: K \\
\hline MAb: & 291 & Pro & Pro & Pro & Pro & Leu & Pro & Pro & $\mathbf{P}$ \\
\hline G7C & 292 & Arg & Arg & Arg & Arg & Arg & Arg & Arg & $\mathbf{R}$ \\
\hline \multirow[t]{3}{*}{ JD312 } & 293 & Glu & Glu & Glu & Glu & Glu & Glu & Glu & $\mathbf{E}$ \\
\hline & 294 & Gln & Glu & Glu & Glu & Glu & Gln & Glu & $\mathbf{E}$ \\
\hline & 338 & Lys & Lys & Lys & Lys & Lys & Lys & Lys & Motif: K \\
\hline Mab: & 339 & Ala & Ala & Thr & $T h r$ & Ala & $T h r$ & Ala & $\mathbf{A}$ \\
\hline PNF69C & 340 & Lys & Lys & Lys & Lys & Lys & Lys & Lys & $\mathbf{K}$ \\
\hline \multirow[t]{5}{*}{ PNF110A } & 341 & Gly & Gly & Gly & Gly & Gly & Gly & Gly & $\mathbf{G}$ \\
\hline & 342 & Gln & Gln & Gln & Gln & Gln & Gln & Gln & $\mathbf{Q}$ \\
\hline & 343 & Pro & Pro & Pro & Pro & Pro & Pro & Pro & $\mathbf{P}$ \\
\hline & 344 & Arg & Arg & Arg & Arg & Arg & Arg & Arg & $\mathbf{R}$ \\
\hline & 435 & His & His & His & $\mathrm{Arg}$ & $\operatorname{Arg}$ & His & His & \\
\hline
\end{tabular}

Key allotypic residues shown in italic: $T h r_{339}$ associated with G3m(u) [26,27] but also present in JIR G3m(st).

${ }^{\text {a }}$ Note that paraprotein GOE G3m(st) possesses $A l a_{339}$ together with paraproteins OM G3m(gu). Leu 291 is associated with G3m(g) [10]. Core pepscan motifs shown in bold (single letter amino acid code: K, lysine; A, alanine; G, glycine; Q, glutamine; P, proline; R, arginine; E, glutamic acid). $\operatorname{Arg}_{435}$, present in paraproteins expressing G3m(u) is underlined.

possess histidine ${ }_{435}$. In using PCImdad, we show that residue 435 is surface accessible and spatially orientated adjacent to the peptide sequence 338-KAKGQPR-344. Consequently we speculate that the proximity of arginine $_{435}$ in conjunction with the peptide motif may play a role in the conformation and phenotypic expression of $\mathrm{G} 3 \mathrm{~m}(\mathrm{u})$. It is, therefore, conceivable that the manner of epitope display afforded by different assay systems could influence the 'dual' reactivity i.e. anti-G3m(u)/ pan-IgG of MAbs PNF69C and PNF110A observed in previous studies $[9,14]$. In the latter, G3m(u) specificity was shown when IgG was captured in ELISA or coated onto red blood cells whereas pan-IgG reactivity was noted with IgG coated directly onto microtitre plates. In this case, hydrophobic interactions between immunoglobulin and a plastic surface could bias the reactivity towards a common IgG epitope as opposed to a potential conformation $(\mathrm{G} 3 \mathrm{~m}(\mathrm{u}))$ epitope.

Epitope mapping of MAbs G7C and JD312 identified the core peptide sequence 290-KPREE-294 that was present in all four IgG subclasses (Table 2) and was consistent with the pan-IgG reactivity exhibited by these antibodies in previous studies $[15,16]$. The latter also serve to demonstrate that the binding of MAbs G7C and JD312 to IgG is not rendered inaccessible by oligosaccharide moieties linked via asparagine 297 [32] or influenced by leucine 291 . PCImdad also highlighted a surface topography for this motif that was highly exposed, solvent accessible and on a loop region (i.e. connecting two B-strands). These observations were consistent with bioinformatic tools [33] which have been used to predict regions of antigenicity on IgG1 Fc [34]: analysis shows the sequence $290-K P R E Q Q Y N-297$ as extremely hydrophilic and thus a likely antigenic site within the $\mathrm{C}_{\mathrm{H}} 2$ domain. Intriguingly pepscan analysis of rheumatoid factors [26-28] likewise highlight an epitope (274KFNWYVD-280) adjacent to the peptide sequence 290-KPREE-294 suggesting a key $\mathrm{C}_{\mathrm{H}} 2$ antigenic region.

Pepscan of all seven MAbs showed reactivity to peptide 62 (360-KNQVSLTCLVKGFYP-374) and to a lesser extent peptide 61 (358-AAQVSLTCLVKGF-372). Since this phenomenon was observed for all control antibodies, it was unlikely that these peptides represented a major epitope for MAbs PNF69C, PNF110A, $\mathrm{G} 7 \mathrm{C}$ and JD312. It was possible that some reactivity could be attributed to non-specific interactions of peptide, MAb and secondary antibody. In terms of location, peptide 62 was situated on the b1 loop and proximal region of the $\mathrm{fx} 2$ face of the $\mathrm{C}_{\mathrm{H}} 3$ domain [13]. Hence this peptide was remote to the $\mathrm{C}_{\mathrm{H}} 2 / \mathrm{C}_{\mathrm{H}} 3$ domain interface and thus unlikely to contribute to epitope(s) recognised by MAbs PNF69C and PNF110A. Minor variations in pepscan profiles were also observed for MAb pairs PNF69C, PNF110A and G7C, JD312 that could reflect subtle differences in the spatial orientation of a MAb for a given epitope. Similar variations in reactivity have been reported in other studies $[15,16]$. Interestingly preliminary data from BIAcore analysis [35] using purified IgG paraprotein immobilised with a goat anti-mouse antibody, highlights differing affinity constants [PNF69C $\left(4 \times 10^{7}\right.$ per M), PNF110A $(7.14 \times$ $10^{7}$ per M), G7C $\left(2.70 \times 10^{8}\right.$ per M), JD312 $\left(2.86 \times 10^{8}\right.$ per M), TM15 $\left(2 \times 10^{8}\right.$ per M)] that might reflect subtle variations in $\mathrm{Mab}-$ epitope interactions.

The present study has shown the combination of pepscan and surface topography visualisation as a means of localising and characterising epitopes of a panel of anti-IgG Fc monoclonal reagents. It is specu- 
lated that the anti-G3m(u) specificity of MAbs PNF69C and PNF110A may be influenced by the presence of arginine $_{435}$ in proximity to the peptide motif expressed in all four IgG subclasses. Overall the MAbs investigated in this study may prove useful probes of antigenic structure e.g. for evaluating recombinant antibodies, or reagents for diagnostic/forensic purposes. In addition, they may serve in functional assays to inhibit the binding of neonatal FcRn (MAbs G7C, JD312) and Streptococcal protein G (MAbs PNF69C and PNF110A) [30].

\section{Acknowledgements}

The authors would like to thank Mimotopes Pty Ltd. for the provision of synthetic peptides.

\section{References}

[1] P.N. Nelson, in: O.M.R. Westwood, F.C. Hay (Eds.), Epitope Mapping. A Practical Approach (Chapter 7), Oxford University Press, Oxford, 2001, pp. 159-197.

[2] R. Jefferis, C.B. Reimer, F. Skvaril, et al., Immunol. Lett. 10 (1985) 223-252.

[3] H. Bull, M. Choy, I. Manyonda, et al., Immunol. Lett. 70 (1999) $143-149$.

[4] P.N. Nelson, G.M. Reynolds, E.E. Waldron, et al., J. Clin. Pathol.: Mol. Pathol. 53 (2000) 111-117.

[5] H.M. Geysen, S.J. Rodda, T.J. Mason, et al., J. Immunol. Methods 102 (1987) 259-274.

[6] B.T. Koshy, A.A. Karande, P.R. Adiga, Vaccine 14 (1996) $307-$ 312.

[7] A.G. Tzioufas, E. Yiannaki, M. Sakarellos-Daitsiotis, et al., Clin. Exp. Immunol. 108 (1997) 191-198.

[8] T. Shakil, M.K. Richardson, E. Waldron, et al., Hybridoma 20 (2001) 199-203.

[9] P.N. Nelson, S.M. Fletcher, G.G. de Lange, et al., Vox. Sang. 59 (1990) 190-197.

[10] P.N. Nelson, M. Goodall, R. Jefferis, Immunol. Invest. 23 (1994) $39-45$.

[11] R.E. Gaensslen, H.C. Lee, E.M. Pagliaro, et al., J. Forensic Sci. 30 (1985) 655-676.
[12] P.N. Nelson, O.M. Westwood, R. Jefferis, et al., Biochem. Soc. Transact. 25 (1997) 373.

[13] A. Feinstein, D. Beale, in: L.E. Glynn, M.W. Steward (Eds.), Structure and Function of Antibodies (Chapter 8), Wiley, Chichester, 1981, pp. 263-306.

[14] P.N. Nelson, S.M. Fletcher, D. McDonald, J. Immunol. Methods 138 (1991) 57-64.

[15] M.I. Nik Jaafar, J.A. Lowe, N.R. Ling, et al., Mol. Immunol. 20 (1983) 686-697.

[16] M.I.B. Nik Jaafar, N.R. Ling, J. Lowe, et al., Mol. Immunol. 21 (1984) 137-143.

[17] Kabat E.A., Wu T.T., Reid-Miller M., et al., US Department of Health and Human Services. Public Health Service, National Institute of Health, fourth ed., 1987, pp. 10-100.

[18] P.L. Yeagle, J.L. Alderfer, A.D. Albert, Mol. Vis. 2 (1996) 12-15.

[19] J. Deisenhofer, Biochemistry 20 (1981) 2361-2370.

[20] S. Laffer, M. Duchene, I. Reimitzer, et al., Mol. Immunol. 33 (1996) 417-426.

[21] C.A. Herve, E.B. Lugli, A. Brand, et al., Clin. Exp. Immunol. 128 (2002) 75-82.

[22] E. Petrakou, A. Murray, M.R. Price, Tumour Biol. 19 (1998) $21-$ 29.

[23] S.D. Dunn, Anal. Biochem. 157 (1986) 144-153.

[24] D.C. Benjamin, S.S. Perdue, Companion Methods Enzymol. 9 (1996) $508-515$.

[25] R.A. Williamson, D. Peretz, C. Pinilla, et al., J. Virol. 11 (1998) 9413-9418.

[26] R.C. Williams, C.C. Malone, Scand. J. Immunol. 40 (1994) $443-$ 456.

[27] C. Peterson, C.C. Malone, R.C. Williams, Mol. Immunol. 32 (1995) 57-75.

[28] V.R. Bonagura, N. Agostino, M. Borretzen, et al., J. Immunol. 160 (1998) 2496-2505.

[29] E. van Loghem, B.G. Grobbelaar, Vox. Sang. 21 (1971) 405-410.

[30] E. van Loghem, B. Frangione, B. Recht, E.C. Franklin, Scand. J. Immunol. 15 (1982) 275-278.

[31] P. Dard, M.-P. Lefranc, L. Osipova, A. Sanchez-Mazas, Eur. J. Hum. Genet. 9 (2001) 765-772.

[32] J. Lund, N. Takahashi, J. Pound, et al., J. Immunol. 157 (1996) $4963-4969$

[33] D. Roden, H.D. Ejtehadi, S. Rowland-Jones, P.N. Nelson, Immunology 104 (2001) 112.

[34] J. Novonty, M. Handschumacher, R.E. Bruccoleri, J. Mol. Biol. 189 (1986) 715-721.

[35] F.C. Hay, O.M.R. Westwood, P.N. Nelson, Practical Immunology, fourth ed (chapter 5), Blackwell Science, Oxford, UK, 2002, pp. $176-177$. 